\title{
Study on Cadmium Accumulation Characteristics of Four Bidens Species
}

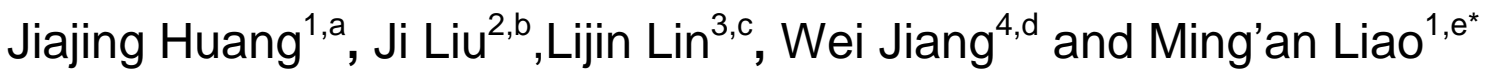 \\ ${ }^{1}$ College of Horticulture, Sichuan Agricultural University, Chengdu, Sichuan, China \\ ${ }^{2}$ Chengdu Academy of Agriculture and Forestry Sciences, Chengdu, Sichuan, China \\ ${ }^{3}$ Institute of Pomology and Olericulture, Sichuan Agricultural University, Chengdu, Sichuan, China \\ ${ }^{4}$ College of Chemistry and Life Science, Chengdu Normal University, Chengdu, Sichuan, China \\ a529112874@qq.com, b34905418@qq.com, 'lli800924@163.com, d1399945180@qq.com, \\ Iman@sicau.edu.cn
}

${ }^{*}$ Corresponding author. Jiajing Huang, Ji Liu and Lijin Lin contributed equally to this work.

Keywords: Bidens; Cadmium; Phytoremediation; Difference

Abstract: A pot experiment was carried out to study the difference of cadmium (Cd) accumulation characteristics of four Bidens species. The results showed that Bidens biternata had the highest biomass and $\mathrm{Cd}$ accumulation amount of whole plant than the other three species under Cd-contaminated soil. The root and shoot biomasses of four Bidens species were ranked as: $B$. biternata $>$ Bidens parviflora $>$ Bidens pilosa $>$ Bidens bipinnata. The Cd contents in roots and shoots of $B$. pilosa were maximal among the four species, and the $\mathrm{Cd}$ accumulation amount of whole plant of those four species was: Bidens biternata $>$ Bidens pilosa $>$ Bidens parviflora $>$ Bidens bipinnata. Therefore, Bidens biternata is the best material among the four Bidens species to remediate Cd-contaminated soil.

\section{Introduction}

With the development of social industrialization, the irrational exploitation and utilization of various resources, the soil heavy metal contamination have been serious increasingly, which has become a limiting factor affecting the development of regional agricultural [1]. Cadmium $(\mathrm{Cd})$ is a toxic heavy metal and high concentration of $\mathrm{Cd}$ could seriously affect the normal growth, yield and quality of crops [1]. Phytoremediation is a technology by planting hyperaccumulator or accumulator into heavy metal-contaminated soil to remove toxic elements from the environment to plants and makes soil non-toxic [2]. The technology has important research value and application prospect in the field of heavy metal contaminated soil because of its advantages of low cost, non-destructive effects on soil structure and no secondary pollution [3-5]. As is well known, we should study and compare the absorption and accumulation abilities of heavy metals of different plants so that the appropriate plant could be selected for phytoremediation and the effect of phytoremediation technology can be applied greatly. The Bidens plants belong to Compositae, which distribute almost all over the country in China and most of them are one year or perennial wild weeds [6]. Some studies have shown that some Bidens species have accumulation ability of $\mathrm{Cd}$, which could be used as a pioneer plant to remove $\mathrm{Cd}$ from the contaminated soil [7-9]. However, there is no comparative study on the Cd accumulation of different Bidens species. Therefore, in this study, a pot experiment was conducted to study the differences of $\mathrm{Cd}$ accumulation of four Bidens species, which aimed at selecting the best species to remediate Cd contaminated soil efficiently.

\section{Materials and Methods}

Materials. In May 2016, the seeds of four species of Bidens including Bidens bipinnata, Bidens pilosa, Bidens parviflora and Bidens biternata were collected from the surrounding farmland at the 
Chengdu campus of Sichuan Agricultural University $\left(30^{\circ} 42^{\prime} \mathrm{N}, 103^{\circ} 50^{\prime} \mathrm{E}\right)$. Then, the seeds were put in the climate chamber to germination and further cultivation and transplanting.

Experimental Design. The experiment was conducted in Chengdu campus of Sichuan Agricultural University from May to July 2016. Soil samples for the experiment were collected from the surrounding farmland at the Chengdu campus of Sichuan Agricultural University. The basic properties of soils were as fallows: the $\mathrm{pH}$ was 7.09 , the total nitrogen content was $1.50 \mathrm{~g} / \mathrm{kg}$, the total phosphorus content was $0.76 \mathrm{~g} / \mathrm{kg}$, the total potassium content was $18.02 \mathrm{~g} / \mathrm{kg}$, the total Cd content was $1.96 \mathrm{mg} / \mathrm{kg}$, the alkali solution nitrogen content was $94.82 \mathrm{mg} / \mathrm{kg}$, the available phosphorus content was $6.30 \mathrm{mg} / \mathrm{kg}$, the available potassium content was $149.59 \mathrm{mg} / \mathrm{kg}$ and the available Cd content was approximately $0 \mathrm{mg} / \mathrm{kg}$. The basic physicochemical properties and Cd content of soils were determined from the methods of the reference [10]. In May 2016, the soils were air-dried and passed through a 6.72-mm sieve. $3 \mathrm{~kg}$ air-dried soil was weighed into each plastic pot $(21 \mathrm{~cm}$ high, 20 $\mathrm{cm}$ in diameter), soaking uniformly by $10 \mathrm{mg} / \mathrm{kg} \mathrm{Cd}$ (in the form of $\mathrm{CdCl}_{2} \cdot 2.5 \mathrm{H}_{2} \mathrm{O}$ ) solution for 4 weeks. All pots were watered each day to keep the soil moisture about $80 \%$, and dug aperiodically to make soil mixed fully. In June 2016, three seedlings of each four species of Bidens with similar growth were transplanted into each pot. For each treatment with three replicates and the pots placed completely random. The distance between pots was $15 \mathrm{~cm}$, and the pot position exchanged aperiodically to weaken the impact of the marginal effects.

Plants were dug up and divided into three parts of roots, stems, leaves after transplanting 60 days, then washed with tap water firstly, followed by deionized water to remove surface dust and soil. After that, the tissues of all plants were dried at $80^{\circ} \mathrm{C}$ until constant weight, weighed, ground to $<0.149 \mathrm{~mm}$, and sealed into plastic bags for analysis. The samples of plant tissues were digested by concentrated $\mathrm{HNO}_{3}$ and $\mathrm{HClO}_{4}$ with 4:1 (vol/vol), and the Cd content were determined by Inductively Coupled Plasma Mass Spectrometry (ICP-MS, iCAP 6300, Thermo Scientific, USA) [11].

Experimental Design. Statistical analyses were conducted using SPSS 13.0 statistical software (IBM, Chicago, IL, USA). Data were analyzed by one-way analysis of variance with least significant difference (LSD) at the $\mathrm{p}=0.05$ confidence level. The following calculated were used: shoot bioconcentration factor $(\mathrm{BCF})=\mathrm{Cd}$ content in shoots / Cd concentration in soil [12]; translocation factor $(\mathrm{TF})=\mathrm{Cd}$ content in shoots / $\mathrm{Cd}$ content in roots [11]; translocation accumulation factor (TAF) $=(\mathrm{Cd}$ content in shoots $\times$ biomass in shoots $) /(\mathrm{Cd}$ contents in roots $\times$ biomass in roots $)[13]$.

\section{Results and Discussion}

Biomass. The difference of biomass of four species of Bidens at the soil Cd concentration of 10 $\mathrm{mg} / \mathrm{kg}$ was showed in Table 1 . The root biomass of four species of Bidens was ranked as: Bidens biternata $>$ Bidens parviflora $>$ Bidens pilosa $>$ Bidens bipinnata. Similarly, the shoot biomass of those four species was ranked as: Bidens biternata $>$ Bidens parviflora $>$ Bidens pilosa $>$ Bidens bipinnata. For the root/shoot ratio of those four species, there was almost no difference among them except Bidens biternata, and the order was Bidens biternata $>$ Bidens bipinnata $>$ Bidens pilosa $>$ Bidens parviflora. The results indicated that Bidens biternata could growth better and has higher tolerance to $\mathrm{Cd}$ than the other three species under $\mathrm{Cd}$-contaminated soil.

Table 1 Biomass of four Bidens species

\begin{tabular}{|c|c|c|c|c|c|c|}
\hline Plant species & $\begin{array}{c}\text { Roots } \\
\text { (g/plant) }\end{array}$ & $\begin{array}{c}\text { Stems } \\
\text { (g/plant) }\end{array}$ & $\begin{array}{c}\text { Leaves } \\
\text { (g/plant) }\end{array}$ & $\begin{array}{c}\text { Shoots } \\
\text { (g/plant) }\end{array}$ & $\begin{array}{c}\text { Total } \\
\text { biomass } \\
\text { (g/plant) }\end{array}$ & $\begin{array}{c}\text { Root/ } \\
\text { shoot ratio }\end{array}$ \\
\hline Bidens bipinnata & $1.29 \pm 0.06 \mathrm{c}$ & $4.03 \pm 0.07 \mathrm{~d}$ & $2.79 \pm 0.06 \mathrm{~d}$ & $6.82 \pm 0.13 \mathrm{~d}$ & $8.11 \pm 0.19 \mathrm{~d}$ & 0.189 \\
\hline Bidens pilosa & $1.74 \pm 0.04 \mathrm{~b}$ & $6.37 \pm 0.09 \mathrm{c}$ & $3.38 \pm 0.09 \mathrm{c}$ & $9.75 \pm 0.19 \mathrm{c}$ & $11.49 \pm 0.23 \mathrm{c}$ & 0.178 \\
\hline Bidens parviflora & $1.78 \pm 0.05 \mathrm{~b}$ & $6.57 \pm 0.08 \mathrm{~b}$ & $4.23 \pm 0.10 \mathrm{~b}$ & $10.8 \pm 0.18 \mathrm{~b}$ & $12.58 \pm 0.23 \mathrm{~b}$ & 0.165 \\
\hline Bidens biternata & $4.63 \pm 0.08 \mathrm{a}$ & $8.69 \pm 0.10 \mathrm{a}$ & $4.47 \pm 0.11 \mathrm{a}$ & $13.16 \pm 0.21 \mathrm{a}$ & $17.79 \pm 0.13 \mathrm{a}$ & 0.352 \\
\hline
\end{tabular}


Cadmium Content. As shown in Table 2, the Cd contents in roots and shoots of Bidens pilosa were maximal among the four species of Bidens. The $\mathrm{Cd}$ contents in roots of the four species were: Bidens pilosa $>$ Bidens bipinnata $>$ Bidens parviflora $>$ Bidens biternata. The Cd contents in shoots of the four species were: Bidens pilosa $>$ Bidens parviflora $>$ Bidens biternata $>$ Bidens bipinnata. For the BCFs in shoots and TFs of the four species of Bidens, all the factors exceeded 1, which indicated that those four species have relatively high accumulation and transportation abilities of $\mathrm{Cd}$.

Table 2 Cadmium content in four Bidens species

\begin{tabular}{ccccccc}
\hline Plant species & $\begin{array}{c}\text { Roots } \\
(\mathrm{mg} / \mathrm{kg})\end{array}$ & $\begin{array}{c}\text { Stems } \\
(\mathrm{mg} / \mathrm{kg})\end{array}$ & $\begin{array}{c}\text { Leaves } \\
(\mathrm{mg} / \mathrm{kg})\end{array}$ & $\begin{array}{c}\text { Shoots } \\
(\mathrm{mg} / \mathrm{kg})\end{array}$ & $\begin{array}{c}\text { Shoot } \\
\text { BCF }\end{array}$ & TF \\
\hline Bidens bipinnata & $8.24 \pm 0.29 \mathrm{ab}$ & $9.67 \pm 0.34 \mathrm{c}$ & $11.37 \pm 0.48 \mathrm{c}$ & $10.37 \pm 0.01 \mathrm{c}$ & 1.04 & 1.26 \\
Bidens pilosa & $8.87 \pm 0.36 \mathrm{a}$ & $12.34 \pm 0.64 \mathrm{a}$ & $23.38 \pm 1.64 \mathrm{a}$ & $16.17 \pm 1.02 \mathrm{a}$ & 1.62 & 1.82 \\
Bidens parviflora & $7.86 \pm 0.41 \mathrm{~b}$ & $11.03 \pm 0.53 \mathrm{~b}$ & $19.44 \pm 0.96 \mathrm{~b}$ & $14.32 \pm 0.73 \mathrm{~b}$ & 1.43 & 1.83 \\
Bidens biternata & $6.46 \pm 0.34 \mathrm{c}$ & $10.15 \pm 0.23 \mathrm{c}$ & $13.52 \pm 1.51 \mathrm{c}$ & $11.29 \pm 0.68 \mathrm{c}$ & 1.13 & 1.76 \\
\hline
\end{tabular}

Cadmium Accumulation. It illustrated the difference of $\mathrm{Cd}$ accumulation amount in four species of Bidens in Table 3. The $\mathrm{Cd}$ accumulation amount in roots of the four species was: Bidens biternata $>$ Bidens pilosa $>$ Bidens parviflora $>$ Bidens bipinnata. The $\mathrm{Cd}$ accumulation amount in shoots was: Bidens pilosa $>$ Bidens parviflora $>$ Bidens biternata $>$ Bidens bipinnata. On the whole, the $\mathrm{Cd}$ accumulation amount of whole plant about those four species was: Bidens biternata $>$ Bidens pilosa $>$ Bidens parviflora $>$ Bidens bipinnata, which turned out that Bidens biternata has higher accumulation ability of $\mathrm{Cd}$ than the others. Moreover, the TAFs of the four species were high, indicating all of them could accumulate Cd preferably.

Table 3 Cadmium accumulation amount of four Bidens species

\begin{tabular}{ccccccc}
\hline Plant species & $\begin{array}{c}\text { Roots } \\
(\mu \mathrm{g} / \text { plant })\end{array}$ & $\begin{array}{c}\text { Stems } \\
(\mu \mathrm{g} / \text { plant })\end{array}$ & $\begin{array}{c}\text { Leaves } \\
(\mu \mathrm{g} / \text { plant })\end{array}$ & $\begin{array}{c}\text { Shoots } \\
(\mu \mathrm{g} / \mathrm{plant})\end{array}$ & $\begin{array}{c}\text { Whole plant } \\
(\mu \mathrm{g} / \mathrm{plant})\end{array}$ & TAF \\
\hline Bidens bipinnata & $10.64 \pm 0.87 \mathrm{c}$ & $38.99 \pm 2.05 \mathrm{c}$ & $31.70 \pm 0.66 \mathrm{c}$ & $70.69 \pm 1.39 \mathrm{~b}$ & $81.33 \pm 2.26 \mathrm{~b}$ & 6.66 \\
Bidens pilosa & $15.44 \pm 0.97 \mathrm{~b}$ & $78.65 \pm 5.19 \mathrm{~b}$ & $79.13 \pm 7.76 \mathrm{a}$ & $157.77 \pm 12.95 \mathrm{a}$ & $173.22 \pm 13.92 \mathrm{a}$ & 10.21 \\
Bidens parviflora & $13.98 \pm 0.34 \mathrm{~b}$ & $72.50 \pm 4.36 \mathrm{~b}$ & $82.29 \pm 6.01 \mathrm{a}$ & $154.79 \pm 10.37 \mathrm{a}$ & $168.77 \pm 10.03 \mathrm{a}$ & 11.09 \\
Bidens biternata & $29.93 \pm 2.09 \mathrm{a}$ & $88.22 \pm 3.02 \mathrm{a}$ & $60.54 \pm 8.24 \mathrm{~b}$ & $148.76 \pm 11.26 \mathrm{a}$ & $178.69 \pm 9.17 \mathrm{a}$ & 5.00 \\
\hline
\end{tabular}

\section{Conclusions}

Among four species of Bidens, Bidens biternata has highest biomass and $\mathrm{Cd}$ accumulation amount of whole plant than the other three species in the same concentration of Cd-contaminated soil. The root and shoot biomasses of four Bidens species were ranked as: B. biternata $>$ Bidens parviflora $>$ Bidens pilosa $>$ Bidens bipinnata. The Cd contents in roots and shoots of B. pilosa were maximal among the four species, and the $\mathrm{Cd}$ accumulation amount of whole plant of those four species was: Bidens biternata $>$ Bidens pilosa $>$ Bidens parviflora $>$ Bidens bipinnata. Therefore, Bidens biternata is the best material among the four Bidens species to remediate $\mathrm{Cd}$-contaminated soil.

\section{Acknowledgements}

This work was financially supported by the Application Infrastructure Project of Science and Technology Department of Sichuan Province (2016JY0258). 


\section{References}

[1] M.L. Yan, L.L. Liu, H.H. Wang, Y.C. Xiang and T. Feng: Journal of Agro-Environment Science Vol. 28, (2009), p. 72.

[2] T.A. Anderson, E.A. Guthie and B.T. Walton: Environmental Science \& Technology Vol. 27, (1993), p. 2630.

[3] J.G. Gu, Q.X. Zhou and X. Wang: Journal of Basic Science and engineering Vol. 11, (2003), p. 143.

[4] D.E. Salt, M. Blaylock, N.P. Kumar, V. Dushenkov, B.D. Ensley, I. Chet, I. Raskin: Bio-technolgy, Vol. 13, (1995), p. 468.

[5] S.P. McGrath and F. Zhao: Current Opinion in Biotechnology Vol. 14, (2003), p. 277.

[6] H.Y. Liu: Chinese Wild Plant Resources Vol. 32, (2013), p. 26.

[7] S.H. Wei, C.J. Yang and Q.X. Zhou: Environmental Science Vol. 29, (2008), p. 2912.

[8] L.L. Dong, X.G. Zhao, S.J. Zhang, Y.H. Zhang, N. Liang and Y.M. Zhao: Chinese Journal of Soil Science Vol. 40, (2009), p. 374.

[9] Y.B. Sun, Q.X. Zhou, L. Wang, W.T. Liu and R. Liu: Environmental Science Vol. 30, (2009), p. 3028.

[10] S.D. Bao: Agrochemical Soil Analysis (3rd edition, China Agriculture Press, Beijing, China 2000).

[11] F. Rastmanesh, F. Moore and B. Keshavarzi: Bulletin of Environmental Contamination and Toxicology Vol. 85, (2010), p. 515.

[12] S.M. Gallego, L.B. Pena, R.A. Barcia, C.E. Azpilicueta, M.F. Iannone, E.P. Rosales, M.S. Zawoznik, M.D. Groppa and M.P. Benavides: Environmental and Experimental Botany Vol. 83, (2012), p. 33.

[13] F.H. Nie: Ecology and Environment Vol. 14, (2005), p. 163. 